\title{
Level of Student Stress Management UHAMKA Guidance Counseling Study Program in Pandemic Covid-19
}

\author{
Asni, Asni ${ }^{1}$, Atin Nur Khotimah ${ }^{1}$, Nurul Fajri ${ }^{1, \text { a) }}$ \\ ${ }^{1}$ Prof. Dr. Hamka University, Indonesia \\ a) Corresponding author, Nurulfajri21@gmail.com
}

\begin{abstract}
The background of this research is the impact of the COVID-19 pandemic which results in learning activities being carried out at home. Learning activities at home often cause stress in students. Especially the final semester students of their thesis are hampered due to limited time for face-to-face guidance, search for reference sources, as well as obtaining research data in the field which is slightly hampered, and for other BK students the online learning system is very ineffective. The purpose of this study was to describe the level of stress management for BK UHAMKA students during the COVID-19 pandemic. The research method used is a descriptive quantitative method. The population of this study was all 584 students of BK UHAMKA, with the research sample including 237 students, sampling using proportional random sampling technique. The instrument used in this study was a stress management scale with a reliability level of 0.948 in the very good category. The data analysis technique used a categorization formula with three categories, namely low, medium, and high. The results showed that 38 students of the stress management level were in the high category (T) with a proportion of $16.0 \%$. Then 165 students of stress management level were in the Medium category $(\mathrm{S})$ with a proportion of $69.6 \%$. Finally, there are 34 students of stress management level in the Low $(\mathrm{R})$ category with a proportion of $14.3 \%$. Based on research results. Based on the results of the research above, it is appealed for the campus, especially the BK study program to improve effective and efficient alternatives in the conditions of the COVID-19 pandemic to facilitate student learning activities.
\end{abstract}

Keywords: Stress Management, Student, The Covid-19 Pandemic.

\section{INTRODUCTION}

The coronavirus disease 2019 (Covid-19) outbreak is a contagious disease caused by a coronavirus that was discovered at the end of 2019 [1]. However, the transmission of Covid-19 was very fast and resulted in death, then the government made various preventive efforts such as Government Regulation Number 21 of 2020 concerning Large-Scale Social Restrictions (PSBB). The practice of PSBB itself is carried out to maintain distance and avoid human associations by implementing learning, working, and worshiping from home [2] The Covid-19 outbreak not only affects the health sector [3], but also has an impact on areas of life such as social, economy [4] and education [5] society. Therefore the covid-19 outbreak is called a pandemic, because many areas of people's life have changed and changed [6]

Especially in the field of education, the Ministry of Education and Culture also responded to the Covid-19 pandemic through the Ministry of Education and Culture's Circular Letter No. 1 of 2020 by prohibiting tertiary institutions from conducting face-to-face (conventional) lectures and ordering lectures or learning online (online) or online [7]. Therefore, a student who is a term for someone who is studying in a tertiary institution, must be supportive in dealing with the impact of the Covid-19 pandemic, which results in 
communication and interaction between students and lecturers, and between students and other students being limited to distance and time and switching. online [7].

Learning methods that are carried out online either through the Whatsapp, Zoom, Google Meet, and other applications used by educators to carry out the teaching process certainly have advantages and disadvantages. [8] The advantages of learning via online are that learning can be carried out flexibly, which is not limited by time and place [9]., so that the interaction between lecturers and students is more intense. Then lecturers can reach students in a wide range [10]. and make it easier for lecturers and students to improve and store learning materials [11].

Online learning also often causes problems for students during the learning process [7]. One of the problems faced by students is a poor internet connection [12], which makes students lose information conveyed by lecturers. Furthermore, the limited mastery of technology for both lecturers and students [13], which results in inefficiency in learning time. Then there is a lack of facilities and infrastructure for each party [7], where students must use internet quotations in a capacity that is more than usual which is not supported by the opinions of parents who have been affected by the Covid-19 pandemic [4]. So that problems like that can affect the psychological condition, especially in students. Such as easily experiencing stress, anxiety, and anxiety [14]. However, the psychological impact is very pronounced on final year students, who are writing their thesis is stress [15]. This is influenced by several factors such as the long time it takes, the process is quite complicated, encouragement from parents who want their children to graduate quickly, supervisors who are difficult to contact [16]. This factor is exacerbated by the conditions of the Covid-19 pandemic, where there is no activity on campus, all guidance processes are carried out via online which causes student stress levels to increase [10]. supervisor who is difficult to contact. [16]. This factor is exacerbated by the conditions of the Covid-19 pandemic, where there is no activity on campus, all guidance processes are carried out via online which causes student stress levels to increase [10]. supervisor who is difficult to contact [16]. This factor is exacerbated by the conditions of the Covid-19 pandemic, where there is no activity on campus, all guidance processes are carried out via online which causes student stress levels to increase [10].

Stress is a condition in which individuals experience pressure from within and from outside which is influenced by various factors, so that there is rejection or unpreparedness from the individual in dealing with certain problems. If the stress experienced by students, especially final students is not handled properly and correctly [17], it will result in a chaotic mindset due to the complexity of the problems faced, so that the effect of not completing the thesis [10] and being threatened in droup out (DO) from the campus and cause other problems, so that the ability to manage stress in students is needed [18]. Stress management is an action to control or regulate stress, this aims to identify the causes of stress and know stress management techniques, so that people can better master stress in life [19]. Therefore, this study aims to determine and describe the stress management of final students of the Counseling Guidance study program, Faculty of Teacher Training, UHAMKA University.

\section{METHOD}

This research method is a descriptive study that describes the stress management of students during the Covid-19 pandemic. The population in this study were all students of the Counseling Guidance study program who were active in 2016-20120, totaling 584 people. The number of samples in this study were 237 students, the sampling method was proportional random sampling where each generation could represent using the Yemene formula.

The instrument used to measure student stress management uses a Likert scale, which will be compiled by researchers based on the main aspects of stress management that have been proposed by Robbins \& Judge. The steps for making this instrument are as follows: (1) Reading various literatures; (2) Based on the existing theoretical studies, a grid will be arranged. The arrangement of the lattice instrument will start from describing the variables until the statement items are formulated to reveal a picture related to students' selfconfidence and social interaction. Furthermore, the researcher conducted a content validity test and the next step was conducting a judgment process to determine the appropriateness of the instrument by the experts to be tested.stress management scale (level reliability 0.948)

The data collected in this study using a closed questionnaire. Data was collected through administering the instruments to students. The steps taken for data collection are as follows: (1) Prepare research instruments. (2) Determining the source of data in research, by contacting the respondent, then preparing the necessary supporting documents such as a research permit and so on. (3) Carry out systematic data collection in accordance with what has been previously planned.

After the data collected were analyzed by means of descriptive analysis used to describe the state of each sub-research variable. To determine the category first by specifying the interval. 


\section{RESULT}

In this section, the researcher will describe the data using descriptive statistics in order to describe the level of stress management in the Guidance study program students as follows:

Table 1 Frequency Distribution and Student Stress Management Categories $(\mathbf{n}=\mathbf{2 3 7})$

\begin{tabular}{lcc}
\hline \multicolumn{1}{c}{ Category } & Frequency & Percentage \\
\hline High & 38 & $16 \%$ \\
Moderate & 165 & $70 \%$ \\
Low & 34 & $14 \%$ \\
Total & 237 & 100.0 \\
\hline
\end{tabular}

Based on table 1 It is known that there are $38 \mathrm{BK}$ students who have high stress management. This is shown by the percentage reaching $16 \%$. Furthermore, there are $165 \mathrm{BK}$ students who have a moderate level of stress management, with a percentage reaching $70 \%$.
And finally, there are $34 \mathrm{BK}$ students who have low stress management, with a total percentage of $14 \%$. So that overall students of BK UHAMKA have a moderate level of stress management.

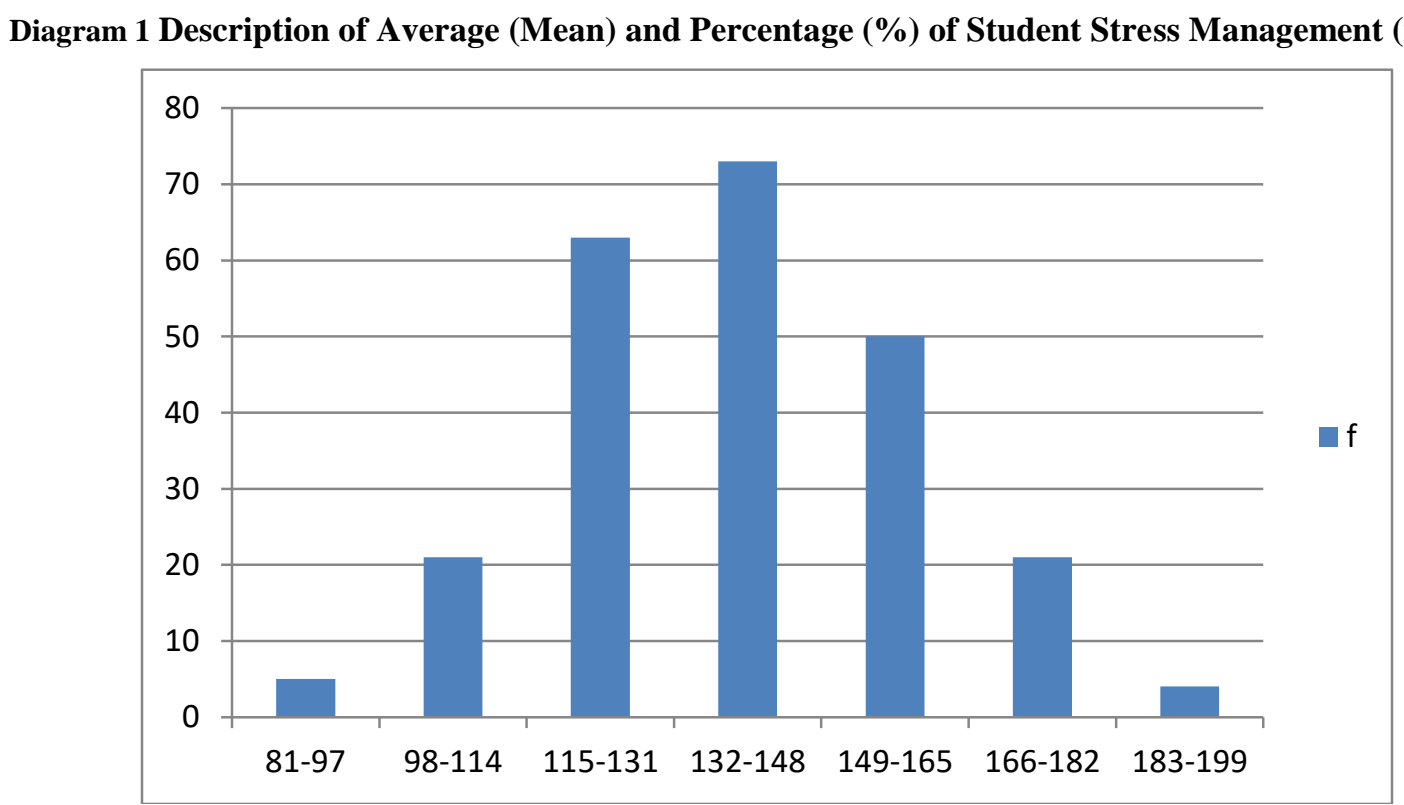

Based on diagram 1 above, we can note that there are 5 students in the $81-97$ score range, then 21 students get scores in the 98-114 range. Furthermore, there were 63 students in the range 115-131, and 73 students obtained scores in the range 132-148. Then there were 50 students in the score range 149-165, and 21 students got scores in the range 166- 183 and the highest score was obtained by 4 students with a score of 183-199. Based on the range of scores obtained by students in accordance with diagram 1 , it proves that the scores obtained by each student vary 
Table 2. Description of Average (Mean) and Percentage (\%) of Student Stress Management Based on Sub Variables $(n=237)$

\begin{tabular}{|c|c|c|c|c|c|c|c|c|c|}
\hline \multirow{2}{*}{ Variable } & \multirow{2}{*}{$\begin{array}{c}\text { Sub } \\
\text { Variable }\end{array}$} & \multicolumn{5}{|c|}{ Score } & \multirow[b]{2}{*}{$\begin{array}{c}\text { Me } \\
\text { an } \\
\%\end{array}$} & \multirow[b]{2}{*}{ SD } & \multirow[b]{2}{*}{ Ket } \\
\hline & & $\begin{array}{c}\text { Id } \\
\text { ea } \\
\text { l }\end{array}$ & $\begin{array}{l}\mathbf{M} \\
\mathbf{i} \\
\mathbf{n}\end{array}$ & $\begin{array}{l}\text { M } \\
\text { ax }\end{array}$ & Sum & $\begin{array}{c}\text { Me } \\
\text { an }\end{array}$ & & & \\
\hline \multirow{5}{*}{$\begin{array}{l}\text { Stress } \\
\text { Managemen } \\
\mathrm{t}\end{array}$} & $\begin{array}{l}\text { Management } \\
\text { Time }\end{array}$ & 40 & $\begin{array}{l}1 \\
4\end{array}$ & $\begin{array}{l}4 \\
0\end{array}$ & 6644 & 28 & $\begin{array}{l}70 . \\
08\end{array}$ & $\begin{array}{c}5,09 \\
1\end{array}$ & $\mathrm{~S}$ \\
\hline & $\begin{array}{l}\text { Build an } \\
\text { Optimistic } \\
\text { Attitude }\end{array}$ & 44 & $\begin{array}{l}1 \\
8\end{array}$ & $\begin{array}{l}4 \\
4\end{array}$ & 8048 & 34 & $\begin{array}{l}77 . \\
18\end{array}$ & $\begin{array}{c}5,68 \\
6\end{array}$ & $\mathrm{~S}$ \\
\hline & $\begin{array}{l}\text { Organize } \\
\text { Activities } \\
\text { Wisely } \\
\end{array}$ & 32 & $\begin{array}{l}1 \\
3\end{array}$ & $\begin{array}{l}3 \\
2\end{array}$ & 5670 & 24 & $\begin{array}{l}74 . \\
76\end{array}$ & $\begin{array}{c}4,34 \\
2\end{array}$ & $\mathrm{~S}$ \\
\hline & $\begin{array}{l}\text { Avoid } \\
\text { Procrastinatio } \\
\mathrm{n}\end{array}$ & 40 & $\begin{array}{l}1 \\
4\end{array}$ & $\begin{array}{l}4 \\
0\end{array}$ & 7275 & 31 & $\begin{array}{l}76 . \\
74\end{array}$ & $\begin{array}{c}4,87 \\
8\end{array}$ & $\mathrm{~S}$ \\
\hline & $\begin{array}{l}\text { Establishing } \\
\text { Harmonious } \\
\text { Communicati } \\
\text { on }\end{array}$ & 28 & 7 & $\begin{array}{l}2 \\
8\end{array}$ & 5199 & 22 & $\begin{array}{l}78 . \\
35\end{array}$ & $\begin{array}{c}3,83 \\
7\end{array}$ & $S$ \\
\hline \multicolumn{2}{|l|}{ Whole } & $\begin{array}{c}18 \\
4\end{array}$ & $\begin{array}{l}6 \\
6\end{array}$ & $\begin{array}{l}1 \\
8 \\
4\end{array}$ & $\begin{array}{c}3283 \\
6\end{array}$ & 139 & 75 & $\begin{array}{c}23,8 \\
33\end{array}$ & $\mathrm{~S}$ \\
\hline
\end{tabular}

Based on Table 2 above, it can be seen that the level of stress management in the BK study program students as a whole the sub-variables are in the Medium (S) category, where the highest score achieved is 80480 the ideal score of 44 in the sub variable builds an attitude of optimism. The next highest score is in the sub variableavoiding the habit of procrastinating with a total of 7275 from the ideal score of 40 . Then followed by the time management sub-variable with a total score of 6644 from the ideal score of 40 . Then in the sub-variable managing activities wisely the total score obtained is 5670 from the ideal score of 32 , and the lowest score is found in The sub variable establishes harmonious communication with a total score of 5199 from the ideal score of 28 .

The overall ideal score is 184 and the overall lowest score is 66 , then the total score obtained as a whole is 32836 . The average score for the overall stress management of students is equal to 139 or it can be presented as a percentage $75 \%$ with the standard deviation being in the value23,833. So that it can be interpreted in the Medium (S) category.

In detail from the results of the data analysis above, it can be seen that the highest average score of student stress management on the sub variable builds an optimistic attitude with an average score. 34 or it can be percentage by value $77.18 \%$ can be interpreted in the Medium category. Then the lowest average score is found in the sub-variables undergoing harmonious communication with an average score of 22 or it can be $78.35 \%$. thus the value can be interpreted in the Medium category (S).

\section{DISCUSSION}

After conducting research on BK UHAMKA students in batch 2016-2019 with a total of 237 respondents / sample, the results showed that the majority of BK UHAMKA students had a moderate level of stress management. This is indicated by the percentage results that reached $70 \%$ or as many as 165 students. And for the high category there are $16.0 \%$ or as many as 38 students. Based on these results it can be concluded that the stress management level of the students is quite good. So that overall students of the BK study program have a fairly good stress management ability, which means that BK study program students in the Covid-10 pandemic are still able to use human resources effectively to deal with all mental and emotional disorders or disorders that arise in response to good enough. The results of this study also show that there are students of the BK study program at the level of stress management who are in the low category with a percentage level of $14 \%$, meaning that students of the BK study program also have a tendency to experience severe stress because they have poor stress management skills in themselves. So that if left unchecked it can interfere with daily activities. According to Robbins \& Judge, that the impact of stress can affect physical health conditions such as headaches, high blood pressure, and can affect a person's psychological condition, such as anxiety, and can even cause depression. The results of this study also show that there are students of the BK study program at the level of 
stress management who are in the low category with a percentage level of $14 \%$, meaning that students of the BK study program also have a tendency to experience severe stress because they have poor stress management skills in themselves. So that if left unchecked it can interfere with daily activities. According to Robbins \& Judge, that the impact of stress can affect physical health conditions such as headaches, high blood pressure, and can affect a person's psychological condition, such as anxiety, and can even cause depression. The results of this study also show that there are students of the BK study program at the level of stress management who are in the low category with a percentage level of $14 \%$, meaning that students of the BK study program also have a tendency to experience severe stress because they have poor stress management skills in themselves. So that if left unchecked it can interfere with daily activities. According to Robbins \& Judge, that the impact of stress can affect physical health conditions such as headaches, high blood pressure, and can affect a person's psychological condition, such as anxiety, and can even cause depression. So that if left unchecked it can interfere with daily activities. According to Robbins \& Judge, that the impact of stress can affect physical health conditions such as headaches, high blood pressure, and can affect a person's psychological condition, such as anxiety, and can even cause depression. So that if left unchecked it can interfere with daily activities. According to Robbins \& Judge, that the impact of stress can affect physical health conditions such as headaches, high blood pressure, and can affect a person's psychological condition, such as anxiety, and can even cause depression.

Furthermore, if we look at the description of the stress management level of students in the BK study program, the range of scores obtained varies widely. Where, the highest score was obtained by 4 students with a score range of 183-199, meaning that there were still students who obtained ideal scores. The individual ideal score in statistics means that the highest score is based on the number of items on the instrument multiplied by the maximum score of the item. And the final score was obtained by 5 students in the score range 81-97. This shows that the difference between students who get the highest and lowest scores is not inversely related. So it can be predicted that there are no students who have outlayer scores.

Based on the results of the calculation of the stress management sub-variable, the results show that UHAMKA BK students in Time Management show a percentage of $70.08 \%$, Building an Optimistic Attitude shows a percentage of $77.18 \%$, Managing Activities Wisely shows a percentage of $74.76 \%$, Avoiding Procrastination shows a percentage of $76.74 \%$, and Establishing Harmonious Communication with a percentage of $78.35 \%$. Thus, the ability to establish harmonious communication has the highest percentage level compared to other sub-variables. As a whole, the sub-variable categorization is in the medium category.

In this case, as a whole UHAMKA BK students are able to have moderate stress management. It can be said that they are able to manage stress quite well. This is shown by the ability to communicate with the environment and peers and the ability to build an optimistic attitude which has a good enough percentage. So there is a tendency to be able to share with friends when experiencing stress. According to the results of research (Saputra, 2016), stress management is also related to a person's optimistic attitude, which is in accordance with the condition of students as respondents. So that the optimistic attitude sub variable has a good percentage.

\section{CONCLUSION}

Based on the results of the data analysis and discussion previously described, several things can be concluded, including the following: Based on the results of the calculation using the categorization formula and processed using SPSS version 25 software, it is found that the stress management level of BK UHAMKA students as a whole is in the medium category with the number of 165 students, or $69.6 \%$. Furthermore, for the high category there were 38 students or $16.0 \%$. And the low category only amounted to 34 students or $14.3 \%$. This means that the stress management skills of UHAMKA BK students are in the medium category. Based on the results of calculations using categorization and processed using SPSS version 25 software to determine the level of each sub-variable of the stress management questionnaire, it was found that overall the stress management sub-variables were in the medium category. With an average percentage of $75 \%$.

\section{ACKNOWLEDGMENTS}

Our gratitude goes to the Counseling Guidance Study Program, Faculty of Teacher Training and Education (FKIP), University of UHAMKA Jakarta for allowing, facilitating and providing information in the form of stress management level data for students we conducted research.

reference

\section{REFERENCES}

[1] E. Supriatna, "Wabah Corona Virus Disease Covid 19 Dalam Pandangan Islam," SALAM J. Sos. Dan Budaya Syar-I, vol. 7, no. 6, Art. no. 6, Apr. 2020, doi: 10.15408/sjsbs.v7i6.15247. 
[2] M. Krisnawati, J. Pitaloka, and A. Jullyandri, "Resiko dan Upaya Pencegahan Pandemi Covid19 Bagi Masyarakat RSPAUD dr. S. Hardjolukito," ABDIMAS Madani, vol. 2, no. 2, Art. no. 2, Jul. 2020.

[3] "(PDF) Deauthorization of the Religious Leader Role in Countering Covid- 19: Perceptions and Responses of Muslim Societies on the Ulama's Policies in Indonesia." https://www.researchgate.net/publication/3433820 57_Deauthorization_of_the_Religious_Leader_R ole_in_Countering_Covid-

_19_Perceptions_and_Responses_of_Muslim_So cieties_on_the_Ulama's_Policies_in_Indonesia (accessed Jan. 23, 2021).

[4] F. D. S. Sumantyo, "Pendidikan Tinggi di Masa dan Pasca Covid-19," J. Kaji. Ilm., vol. 1, no. 1, pp. 81-92, Jul. 2020, doi: 10.31599/jki.v1i1.266.

[5] "Covid-19, Family, and Information Literacy Pamungkas KOLOKIUM." http://kolokium.ppj.unp.ac.id/index.php/kolokium -pls/article/view/395 (accessed Jan. 23, 2021).

[6] N. Fitriasari, "Pencegahan Primer Membentuk Masyarakat Sehat Di Era Covid-19," SALAM J. Sos. Dan Budaya Syar-I, vol. 7, no. 12, Art. no. 12, Dec. 2020, doi: 10.15408/sjsbs.v7i7.15407.

[7] "Dampak Covid-19 Terhadap Kegiatan Pembelajaran Online di Sebuah Perguruan Tinggi Kristen di Indonesia | Perspektif Ilmu Pendidikan."

http://journal.unj.ac.id/unj/index.php/pip/article/vi ew/14921 (accessed Jan. 23, 2021).

[8] D. H. Oktawirawan, "Faktor Pemicu Kecemasan Siswa dalam Melakukan Pembelajaran Daring di Masa Pandemi Covid-19," J. Ilm. Univ. Batanghari Jambi, vol. 20, no. 2, p. 541, Jul. 2020, doi: 10.33087/jiubj.v20i2.932.

[9] "Melatih Keterampilan Berpikir Tingkat Tinggi Dalam Pembelajaran Matematika Pada Siswa Sekolah Dasar | Hidayati | Terampil: Jurnal Pendidikan dan Pembelajaran Dasar." http://ejournal.radenintan.ac.id/index.php/terampil /article/view/2222 (accessed Jan. 22, 2021).

[10] S. H. Harahap, "Pemanfaatan E-Learning Berbasis Lcms Moodle Sebagai Media
Pembelajaran Untuk Mata Kuliah Sistem Informasi Akuntansi," J. Ris. Akunt. Dan Bisnis, vol. 15, no. 1, Art. no. 1, Nov. 2015, doi: 10.30596/jrab.v15i1.429.

[11] E. Karwati, "Pengaruh Pembelajaran Elektronik (E-Learning) terhadap Mutu Belajar Mahasiswa," J. Penelit. Komun., vol. 17, Jul. 2014, doi: 10.20422/jpk.v17i1.5.

[12] M. Syah, "Psikologi pendidikan," 2016.

[13] J. Ahiri, L. Dunifa, A. Tanduklangi, and A. R. A. Ghani, "The Effect of Learning Strategies on Higher-Order Thinking Skills Students with Different Learning Styles," vol. 4, no. 9, p. 8, 2013.

[14] "Hubungan Kecerdasan Emosional Dan Stres Akademik Pada Mahasiswa Yang Mengikuti Organisasi Dan School From Home | Prosiding Seminar Nasional LP3M." http://proceeding.semnaslp3m.unesa.ac.id/index.p hp/Artikel/article/view/85 (accessed Jan. 23, 2021).

[15] 131211132010 Jihan Nisa Afdila, "Pengaruh Terapi Guided Imagery Terhadap Tingkat Stres Pada Mahasiswa Tingkat Akhir Dalam Menyelesaikan Skripsi," skripsi, Universitas Airlangga, 2016.

[16] R. Permatasari, "Studi Deskriptif Dampak Psikologis Mahasiswa Program Studi Bimbingan dan Konseling Universitas PGRI Banyuwangi Dalam Penyusunan Skripsi di Masa Pandemi Covid-19," J. Bina Ilmu Cendekia, vol. 2, no. 1, Art. no. 1, Jun. 2020.

[17] S. Rachmanissa, "Social Network Analysis: Stres Akademik Pada Mahasiswa Dalam Pemberlakuan Kuliah Secara Daring Dalam Masa Pandemi Covid-19," p. 17.

[18] M. Muslim, "Manajemen Stress Pada Masa Pandemi Covid-19," ESENSI J. Manaj. Bisnis, vol. 23, no. 2, Art. no. 2, Aug. 2020.

[19] "Studi Eksplorasi Dampak Work From Home ( WFH ) Terhadap Kinerja Guru Selama Pandemi Covid-19 | EduPsyCouns: Journal of Education, Psychology and Counseling." https://ummaspul.ejournal.id/Edupsycouns/article/view/418

(accessed Jan. 23, 2021).

